\section{FÛZFA Balázs}

Eötvös Loránd Tudományegyetem

Savaria Egyetemi Központ

ORCID: 0000-0002-9289-5547

fuzfa.balazs@sek.elte.hu

\section{„Itt kezdődött a posztmodern?" Adalékok az irodalmi tudat alakulásához a Trieszt-Szombathely- Köszeg-Bécs-Prága nagyrégióban a késő modernség idején ${ }^{1}$}

Az irodalmi regionalitás kérdései mindig is érdekelték a kutatókat, ám - néhány kivételtől eltekintve - ez a szempont mégsem vált sem az irodalomtudomány, sem az irodalomtanítás kiemelt területévé (utóbbiban 2005, azaz a kétszintü érettségi bevezetése óta szerepel).

A szerző hipotetikusan a XX. század kanonikus világirodalmi müveire (Joyce, Musil, Rilke), illetve azok poétikai hasonlóságaira alapozza kijelentését, mely szerint az irodalmi modernség egyik bölcsője a Borostyánkőút Európán átívelő kulturális csatornája lehetett, melynek szerves része a magyar irodalom is - elsősorban Ottlik Géza Iskola a határon címü regénye révén. Ottlik müve éppen azt a korszakot dolgozza fel (1923-1926), melyben karakterisztikusan megjelentek a posztmodern poétika jegyei: a mellérendeltség, a párhuzamos nézőpontok, az idősíkok felbontása stb.

Például a „Trieszti-öböl” (Joyce, Ottlik) tehát úgy lesz a modernség bölcsője, hogy Duinótól (Rilke) Trieszten és Szombathelyen (Joyce), továbbá Köszegen (Ottlik) át ível az út Bécsig (Musil) és Prágáig (Kafka). Ebből pedig kiemelhető (sok más mellett) egy olyan tematikus problémasor, mint például a „katonaiskolás szerző”-k lehetséges nézó-pontja; amely lényegében nem más, mint egy velük azonos korban alkotó irodalomtudós determináns szempontja, jelesül a katonaiskola-szövegek „kronotoposz” meghatározta jellege (Bahtyin).

A címben jelzett fö hipotézis („Itt kezdődött a posztmodern...”) akár túlzónak vagy játékosnak is mondható, ám a szerző reménykedik benne, hogy nézőpontja néhány adalékkal hozzájárulhat a szóban forgó kiskorszak poétikai világának értelmezéséhez.

Kulcsszavak: posztmodern, nagyrégió, Joyce, Kafka, Musil, Ottlik, Rilke

„A probléma problémája többnyire a léte, a léte vagy nem-léte, azazhogy nincs módunkban öt fölismerni, nem tudjuk, hogy vékony jégen járunk, s alattunk dühösen morog a sértett folyó."

(Esterházy Péter)

„A magyar irodalom történeti önismeretében, szemben a magyar politikai kultúra [...] regionális jellegú változataival, vol-

\footnotetext{
${ }^{1}$ Dolgozatom a Pázmány Péter Katolikus Egyetem 2017. május 19-20-án, Budapesten rendezett prózakonferenciáján elhangzott előadás erősen átdolgozott és bővített változata, mely egyben bevezetése egy később elkészülő nagyobb tanulmánynak. Az ennek alapját képező kutatás a kőszegi Felsőbbfokú Tanulmányok Intézete (iASK) ösztöndíjas támogatásával zajlott 2016-17-ben.
} 
taképpen szokatlan az írói egyéniségek és az irodalmi müvek regionális szempontú szemlélete és vizsgálata."

(Pomogáts Béla)

\begin{abstract}
„Párizs és Szentpétervár mellett, azokkal teljesen egyenrangú módon Bécs-Budapest-Prága-Krakkó-Zágráb-Trieszt nem csupán a nemzeti kultúra új fázisainak adnak teret, hanem részint annak a régiónak a megformálódását is segítik, amelynek a magam részérôl a Kelet-Közép-Európa nevet ajánlottam."
\end{abstract}

(Fried István) [...] „Kelet-Közép-Európa virtuális szellemi tér, amely fogalmilag ritkán kap határozott kontúrokat, szellemileg, müvekben, a kultúrában és a kulturális közösségekben, összeszövődöttségben azonban létező, munkáló tényező, amely hirtelenváratlan rendkívüli - szellemi, irodalmi - sikerekkel, persze, nemcsak azokkal, azt a ráismerést érzékelteti, amikor a sajátban megbúvó idegen és az idegenben megbúvó saját tudomásul veszi a maga összetettségét."

(Fried István)

Mindenekelőtt le kell szögeznünk: problémafelvetésünk vállaltan önkényes és kísérleti jellegü.

Nézetünk szerint az irodalom történetének és jelenének egyaránt meghatározó minőségi jellemzője lehet a „regionalitás” fogalma, melyet itt most a szó tágabb és szűkebb értelmében egyaránt használunk. Az irodalomtudomány bizonyos irányzatai különösen az utóbbi évtizedekben foglalkoznak előszeretettel a nemzeti irodalmak további differenciálásával - alárendeltség és fölérendeltség szempontjából egyaránt. Így születtek olyan jelentôs irodalomtudományi interpretációs elméletek a múlt század '80-as, '90-es éveiben, mint például a posztkolonializmus, a feminista irodalomtudomány vagy az ökokritika. E nézőpontok a posztstrukturalista irányzatok - pszichoanalízis, dekonstrukció, recepcióesztétika stb. - talaján jöttek létre, ám vizsgálódási szempontjaik az irodalom jelenségeinek a korábbiaknál egy szűkebb korpuszára irányultak. Az adott korpusz pedig immár a társadalom életének egy konkrét módozatával volt kapcsolatos: kijelölődött valamely differencia specifika, melynek mentén aztán felépült egy önálló értelmezésháló (feminizmus, környezettudatosság stb.).

A „regionális irodalmak” bizonyos értelemben mindig is az irodalomtudomány érdeklődésének homlokterében álltak, ám önmaguk definiálásakor elbizonytalanodni is látszottak. Mintha nem lett volna elég muníciónak az önálló korpusszá történő kijelölődéshez a földrajzi koordináta, a népszokás vagy bármilyen más rétegelv. A fogalmat „regionális irodalom” - szűkebb értelemben használtuk, ám pontosan definiálni bátortalanok voltunk. Talán nem hangzik elég tudományosan?

Az utóbbi évtizedekben vetődött föl a kérdés, hogy a regionalitás az irodalom történetének alakulásában mélyebb szerepet játszhat, mint azt első megközelítésre gondolnánk. Azaz nemcsak a szerző vagy a mű születésének, cselekményének körülményei határolhatják be a regionalitás jellegét, hanem az adott művek olyan esztétikai jellemzőkkel rendelkezhetnek, amelyek vagy csakis az adott helyen jöhettek létre, vagy megteremtő- 
désükhöz szükség volt arra, hogy a szerző rendelkezzék az adott helyre vonatkoztatható valóságreferencialitás ismeret- és viszonyrendszerével.

Az irodalmi tudatnak a művek születésén kívül természetesen fontos része az irodalom kortárs recepciója is. A kutatás ezen a területen végképp gyerekcipőben jár. Jelenleg nincs tudomásunk olyan szakirodalmi alkotásról, amely ebből a szempontból venné figyelembe vagy tárgyalná a szóban forgó nagyrégió irodalmi produktumait. Természetesen ez egy külön kutatás tárgya lehet a későbbiekben, mi magunk tervezzük is számba venni az adott régióban az 1910 és 1930 között megjelent recepciós munkákat (elsősorban Rilke és Joyce korszakformáló műveivel kapcsolatban). Érdekes felismerések alapja lehet, ha a szomszéd országok (birodalmak vagy azok alrégiói) a mondott korban kölcsönösen releváns értelmezői viszonyba kerültek egymással - legalább az irodalmi alkotásokon keresztül.

A posztmodernség poétikai eszköztára modellációjának vizsgálata pedig további kisebb kutatási irányokat rejthet - ez elsősorban a főtéma bővítését jelentheti, mindenekelőtt a temporalitás szempontjának fokozott horizontba emelésével. Kézenfekvő lehet például Berzsenyi Dániel költészetének mint a modernség előfutárának a regionalitás szempontjából történő vizsgálata (vö.: Búcsúzás Kemenesaljától!) vagy Weöres Sándor lírájának elemzése a regionalitás nyelvi elemeinek megjelenése okán (vö. például Vas megyei üdvözlet stb.), továbbá Ottlik Géza Iskola a határonjának szövegelemzése motivikus és regionális szempontból („szombathelyi országút” stb.) (később erről még bővebben szólunk dolgozatunkban).

Hipotézisünk szerint az 1920-as évek körül a Duinótól (Rilke) és Trieszttől (Joyce) Szombathelyen (Joyce) és Kőszegen (Ottlik) keresztül Bécsig (Musil), sőt Prágáig (Kafka) terjedő irodalmi nagyrégióban - lényegében a Borostyánkőút mentén - jött létre az irodalmi modernség poétikai eszköztárának első modellációja, és születtek meg alapművei (Duinói elégiák, Ulysses, A tulajdonságok nélküli ember, A per stb.)

„Az európai kultúra és maga a hagyományos európai társadalom, akkor, amidőn a középkor, majd a reneszánsz világában az európaiság fogalma egyáltalán megjelent, nem nemzeti államok szerint szerveződött, nem is léteztek akkor nemzeti államok, hanem régiók, regionális struktúrák szerint. A régiók később, már a nemzeti államok és a keretükben végbemenő polgárosulás idején közös állami keretbe kerültek, ez az állami keret mindazonáltal időnként megváltozott, például a német és az olasz állam története során. A regionális szerveződések és ennek következtében a regionális identitások, a regionális kultúrák mindennek ellenére fennmaradtak, vagy ha elmosódtak volna, időnként újraszerveződtek, új életet kaptak. Valójában a polgári társadalmak és a nemzeti államok kialakulása során, tehát a 19. és a 20. században is érzékelhetők voltak azok a törekvések, amelyek a korábbi regionális hagyományok felújítását tűzték célul maguk elé. Mintha az államépítő és ennek megfelelően a nemzeti egység megteremtésére irányuló politika erősen központosító törekvéseivel szemben időről időre új öntudatra ébredtek volna a tradicionális történelmi és kulturális képződmények, a nemzeti kereten belül külön színeket képviselő népcsoportok, a nemzeti kultúrán belül külön karaktert mutató kulturális regionalizmusok." (Pomogáts 2010: 5) 
A közbeszédben a „nagyrégió” fogalma általában nem terjed túl az országhatárokon. Ugyanakkor találhatunk utalásokat például „Duna-régió”-ra is, kétségtelenül eme határokon átívelő értelemben (Hardi 2010). A fogalom használatának sokrétűségére mi sem jellemzőbb, mint Jeney László előadásának felosztása:

„Regionális terek (mezoszintek)

- Nagytérség (országrész, makrorégió)

- Régió (gazdasági körzet, mezorégió)

- Megye (alrégió)

- Járás (kistérség, kistáj, városkörnyék, mikrorégió)." (Jeney 2013)

E felosztásban nem találjuk a használni kívánt fogalmat az általunk felvetett értelemben. Vajon akkor lehetséges-e, hogy a Borostyánkőútról (pontosabban annak egy részéről) mint esztétikai értékek alapzatáról, gyökeréről beszéljünk? Kétségtelen, hogy - maradva példánknál - a Borostyánkőút az útépítés és a kereskedelem révén megsokszorozta a lehetséges emberi kommunikációs gesztusok mennyiségét. Azaz emberek, értékek, nyelvek, kultúrák találkozásának tereit hozta létre. Amely terek ráadásul állandó mozgásban voltak, képzetünk szerint szinte eltéveszthetetlenül „sodorták magukkal” a résztvevőket egymás felé - évszázadokon keresztül.

Az Iskola a határon regionalitással - eme nagyrégióval - kapcsolatba hozható motívumait kutatva például szembeötlő a Trieszti-öböl többszöri szerepeltetése a regényben. Korábban e témát egy tanulmányban már kifejtettük ${ }^{2}$, itt most csak arra utalunk, hogy a földrajzi név - Ottlik egyedi helyesírásával (általában: „Trieszti Öböl”, egyszer: „trieszti öböl”) - 12 alkalommal szerepel a szövegben, $\mathrm{s}$ az előfordulások némi szabályosságot is mutatnak, mintegy „keretezik” a regényt. A „katonaiskola” mint motívum szintén országhatárokon kívüli, nagyrégiós jelentésben fordul elő kétszer is Colalto hiányjegyzékgyűjteménye kapcsán: „A napos a papírkosárral kísérgette az asztalsorok közt. Akinél még nem járt, vigyázzban állt, s a tanszerládák fedele ki volt nyitva. Schulze gúnyos arccal turkált a holminkban. Colaltótól azonban nem a gombcsapatát szedte el, a kapusként szolgáló fél szerecsendióval, hanem a féltett hiányjegyzék-gyüjteményét. Egy nagy füzetben voltak felragasztva ezek az évszám, aláírás, tantárgy és iskola - Kismarton, Sankt Pölten, Morva-Fehér-templom, Bécsújhely - szerint osztályozott, sokszor sérült, töredékes cédulácskák, amiket Colalto régi tankönyvek, térképek fedőlapjának belsejéből bányászott ki; s a füzetben préselődtek a még feldolgozásra és beragasztásra váró újabb szerzeményei is. Még magam is sápadtan néztem, hogyan dobja Schulze papírkosárba Colalto hosszú tudományos kutató munkájának drága gyümölcsét. Vacsora előtt tettem neki valami megjegyzést. De Colalto vállat vont. Nem akart erről beszélgetni." (Ottlik 1975: 219) De felfüzhető a gondolatmenetre egy másik régiós motívum is a regényből, például a hazautazásoké -Budapestre Győrön és Komáromon, Tatabányán keresztül (hangsúlyosan szerepelnek a szövegben az állomások nevei, amelyeket a cőgerek fejből tudnak és zsolozsmáznak), illetve a regény végén a Mohácsra történő hajózás leírása. Ezek a szimbolikus szöveggesztusok ugyan nem illeszkednek a Borostyánkőút mentén szerveződő nagyrégiós elgondolásunkba, de jelzik, hogy egy regényszövegben a térképzeteknek eme szintje is jelentésteremtő erő lehet.

A kimozdulás és az elmozdulás, helyváltoztatás, az utazás toposza egyre fontosabbá válik a Candide után az irodalomban. Az Iskola a határonban minden kisebb-nagyobb

\footnotetext{
2 Részletesebben lásd erről a szerző egy korábbi munkáját: Fűzfa Balázs (2017)
} 
kimozdulás egyenesen „kiszabadulás”-sal ér föl. A percnyi kintlét a katonaiskola bezártságából maga a felmérhetetlen szabadság. Medve híres szökési jelenetsorában csúcsosodik ki ez a jelentésszál és értéktartalom.

S vajon van-e fontosabb jelentésrétege az Ulyssesnek, mint az utazás térben és időben, lélekben? Vagy A kastélyban a belső bolyongás? És $A$ tulajdonságok nélküli embernek vajon van-e fontosabb rétege, mint ugyanezek? Íme, a felütés:

„Alacsony nyomású légtömegek úsztak az Atlanti-óceán felett; keletnek tartottak, az Oroszországot borító magas nyomású légtömegek felé, és eddig semmi hajlandóságot nem mutattak, hogy északi irányban kitérjenek. Működtek az izotermák és az izotérák. A levegő hőmérséklete szabályszerűen aránylott az évi középhőmérséklethez, a leghidegebb és a legmelegebb hónap hőmérsékletéhez, valamint a havi aperiodikus hőmérséklet-ingadozáshoz. A Nap és a Hold kelte-nyugta, a Hold, a Vénusz és a Szaturnuszgyűrű fényváltozása és még sok más fontos jelenség mind megfelelt a csillagászati évkönyvek előrejelzéseinek. A levegőben csúcspontra ért a vízgőz feszítőereje, a páratartalom csökkent. Egyszóval, ami e tényállást régimódian bár, de igen alkalmasan kifejezi: 1913-at írtak, és szép augusztusi nap volt.

Autók szökkentek elő keskeny, mély utcaszurdokokból sekély fénytócsa-terekre. Gyalogostömegek gomolyogtak felhősáv-vonulásként. Ahol a sebesség erőteljesebb vonalakat húzott sietős lazaságukba, megsűrűsödtek, gyorsabb lett áramlásuk, hogy azután e pár kilengést újra egyenletes lüktetés kövesse. Hangok százai fonódtak egymásba, drótszövedék-zajjá; s ebből kis csúcsok álltak ki, vakmerő élek indultak-simultak el, tiszta hangok pattantak-röppentek. E zajból, bár sajátosságai nem kottázhatók le pontosan, sokévi távollét után, hunyt szemmel is megállapíthatja bárki, hogy a monarchia székesfővárosában, Bécsben jár. A városok felismerhetők a járásukról, akárcsak az emberek. És ha az iménti bárki a szemét is kinyitná, ugyanazt nyugtázhatná az utcák lüktetése láttán, méghozzá jóval előbb, hogysem valamiféle jellegzetes kicsinység, nyomra vezethetné. És az sem baj, ha mindezt csak úgy képzeli. Hordaidőkbeli örökség, hogy a tartózkodási hely kérdését olyannyira túlbecsüljük; akkoriban a táplálkozás helyét kellett megjegyezni. Nem ártana tudni, miért elégszünk meg a vörös orr esetében azzal a pontatlan meghatározással, hogy vörös; miért nem kérdezünk tovább, milyen is a vörössége, holott hullámhossza, segítségével mikromilliméternyi pontossággal megállapíthatnánk; míg efféle sokkal bonyolultabb képződményekben, mint például a város, ahol tartózkodunk, mindig és mindenáron tudni szeretnénk, jelesül melyikről is van szó. Ez pedig fontosabb dolgokról tereli el a figyelmet." (Musil 2013: 5)

S nem ugyanígy kezdődnek-e, nem ugyanerről beszélnek-e Rilke Duinói elégiái?

„Hogyha kiáltanék, ki hallana engem

az angyalok rendjéből? és ha netán a szivére

vonna hirtelen egyik: én belepusztulnék

az erősebb lét közelébe. Mert hisz a Szép nem más,

mint az iszonyu kezdete, mit még elviselünk,

s mennyire bámuljuk, mert megveti szenvtelenül, hogy

összetiporjon. Iszonyu minden angyal.

Így visszafogom magamat, elnyelve sötét zokogásom

hívó szavait. Ki volna az hát,

aki kellene nékünk? Angyal nem, nem is ember, 
és a fülelő állatok észreveszik már, hogy mily bizonytalanul vagyunk mi otthon a megfejtett világban. Mienk marad tán valamely fa a dombon, hogy naponta viszontlássuk, mienk maradhat a tegnapi utca, egy-egy szokás hűsége, mely megmakacsolta magát, megtetszett neki nálunk és nem ment, s itt maradt."

(Nemes Nagy Ágnes fordítása)

A huszadik század elejével ránk köszöntő elbizonytalanodásnak keres nyelvi formát a modern költészet a múlt század elején - és itt most elsősorban Einstein relativitáselméletére gondolunk ( $E=m c^{2}$ [1904]) Rilkével és Adyval párhuzamban („Minden Egész eltörött” [1909]). Ezt a keresést folytatja az Iskola által megidézett Triesztben Joyce, amikor írja az Ulyssest - mely titokzatosan összefügg Magyarországgal, Szombathellyel, hiszen Leopold Bloom felmenői a regényi fikció szerint ez utóbbi városban születtek. Az Ulysses pedig alig egy évvel jelenik meg előbb, mint amikor Medve Gábor kinéz a kőszegi iskola hálótermének ablakán, s ellát egészen Triesztig:

„A hálóteremnek három irányba néztek az ablakai, délnyugatra, északnyugatra és északkeletre. M. az egyik délnyugati, vagyis az épület homlokzata felőli ablakban könyökölt. Alkonyodott. A nap már lebukott a hegyek mögött, de még nem volt este. Egyáltalán nem volt este, majdnem világos nappal volt. A napot csak eltakarták a Keleti Alpok nyúlványai, de voltaképpen még nem szállt le. Tisztán meg lehetett különböztetni odalent a színeket, a lombok zöldjének többféle árnyalatát is. Csak a főalléba kezdett betelepülni lassacskán az esti sötétség, amelyet a fasor gyéren elhelyezett vasoszlopos lámpái sem tudnak majd eloszlatni. Erős hegyi levegő mart jólesően M. arcába; elkalandoztak a gondolatai; elindultak kifelé a hosszú főallén, a százéves fák emeletmagas sátra alatt, vissza az úton, amerre reggel befelé jött az anyjával; keresztül a park ölén, ki a főkapun, át a patak kis hídján meg a másikon, a felduzzasztott malomág kőhídján s a sikátorszerű utcácskán vissza a kisvárosba, végig a főutcán, elhagyva a várfal maradványait, a templomot, a bencés gimnáziumot meg a kis tér sarkán az Arany Strucc Szállodát, ahol az előző éjszakát töltötték, ki az állomásra és még tovább, az ismeretlen-ismerős nagyvilágba, amely Verne-regények tájaiból, francia nyelvkönyve képeiből, emlékeiből és vágyaiból tevődött össze, végtelen volt és rejtélyesen izgalmas, s melyet egy szokatlan arc, furcsa világítás, új íz vagy ismeretlen szag bármikor fel tudott idézni. M. távoli, magányos lovasokra gondolt, a trieszti öbölre, egy régi-régi, talán három vagy négy évvel ezelőtti karácsony éjszakára, a tegnap esti kocsizásra a városka aszfaltos főutcáján, Kehrling Béla teniszbajnokra, kovászos uborkára, mohos sziklára, fehér vitorlára; így jött az esti lehülés. De még nem volt este, csak leszállt a nap a hegyek mögé. M. nézte az eget, és látta is, amit néz. Közel kilencszázszor fog még így leszállni a nap az Alpok nyúlványai mögé, de ő soha többé, vagy legalábbis rettenetesen sokáig nem fogja látni, amit néz." (Ottlik 1975: 26-27)

Nemcsak a tér(koordináták) pontos meghatározásának (Kőszeg városa), hanem a tér szemléletének is ugyanolyan fontossága lesz a regényben, mint a föntebb idézett Musilszövegben Bécsnek, ugyanolyan, mint amilyen lényeges motívum Rilkénél „a tegnapi utca" és Joyce-nál Dublin, Kafkánál a kőbánya $A$ per záró jelenetében ${ }^{3}$. S ha tüzetesebben

\footnotetext{
3 „Némi kölcsönös udvariaskodás után - arról volt szó, ki hajtsa végre az elkövetkezendő feladatokat, mert ezt, úgy látszik, nem osztották meg az urak közt - az egyik úr odament K.-hoz, lehúzta róla a kabátját, mellényét és végül az ingét is. $K$. akaratlanul is megborzongott, $s$ az úr erre könnyedén, megnyugtatóan hátba vágta. Aztán gondosan rendbe rakta K. holmiját, mintha még szükség lenne majd rá, ha nem is a legközelebbi időben. Hogy
} 
nézzük a szövegeket, akkor arra is rájöhetünk, hogy ezek a térképzetek igen közel állnak a bahtyini kronotoposz fogalmához: mindannyiszor, amikor térről beszélnek, idősíkokat (is) jelölnek, és mindannyiszor, amikor idősíkokat jelölnek, ezt különböző terekben és téri értelemben is teszik. „A kronotoposz a mi értelmezésünk szerint - írja Mihail Bahtyin az irodalomban egyszerre formai és tartalmi kategória. Az irodalmi-művészeti értelemben vett kronotoposzban a tér- és időbeli ismérvek konkrét, tartalmas egységben olvadnak öszsze. Az idő itt besűrűsödik, összetömörül, művészileg látható alakot ölt; a tér pedig intenzívvé válik, időfolyamattá, szüzsévé, történetté nyúlik ki. Az idő tulajdonságait a tér tárja föl, a tér viszont az időn méretik meg és töltődik föl tartalommal. E kereszteződések, a tér- és időbeli ismérveknek ez az összeolvadása határozza meg a művészi kronotoposz jellegét." (Bahtyin 1976: 257-258) ${ }^{4}$

A többnézőpontúság és a szövegpolifónia mindegyik alkotás jellegzetessége, ugyanakkor kétségtelen, hogy a tér- és időpoétika úgy válik meghatározóvá, hogy „észre sem vesszük" tér és idő egymásba való kronotopikus áttűnéseit. Ennek jelentőségét és poétikai szerepét Faragó Kornélia világítja meg élesen számunkra:

„Amikor az értelmezés azt kérdezi, hogy milyen jelentésadási gesztusok kötődnek a tér poétikájához, amikor a regény más »szubsztanciáit«, aktánsait, oktánsait és időviszonyait a térvonatkozások összefüggésrendszerében közelíti meg, nem a helyszíni térformák anyagban létező világa, a táj materiális formája, a hipotipózis alakzatában kibontható geográfiai és topográfiai dimenzió kerül előtérbe. Erősebben kérdez rá a következőkre: a térviszonylati perspektíva szerepére, az aktussorozatokban kibontakozó térviszonylatokra (...), a változásban-, az áthelyeződésben-, a kiterjedésben-, az összezsugorodásbanlétezésre, a bennfoglalás, az érintkezés, a metszés topológiai viszonyaira. Az elvont fogalmakkal leírható téralakzatok, a szereplők közötti elrendezés elvont fogalmakkal leírható viszonylatai, az erőtér, a kommunikációs tér, a nyelvileg/képzetszerűen teremtődő térjelentések állnak az olvasói figyelem középpontjában. A narratív megismerésben megnyilvánuló érzelmi, érzéki viszonyok és gondolati tartalmak téries konfigurációja. A belső világtérben, a szellemi élet térségeiben megjelenő, időformát öltő térképzetek, az emlékek, az álmok, a tervek, a vágyak és utópiák, a szándékok struktúraformáló térmetaforái. Mindenekelőtt az emlékezet narratív stratégiái, amelyek a regény poétikájából a szenzitív benyomásokra építő formálást hangsúlyozzák: az érzet-szenzációk (fény- és színérzékelés, a

\footnotetext{
K. ne álljon mozdulatlanul a húvös éjszakai levegőn, karon fogta, s egy kicsit föl-le járkált vele, míg a másik úr valami megfelelő helyet keresett a kőbányában. Amikor megtalálta, intett, és a másik úr odakísérte K.-t. A szakadékos fal közelében egy leomlott kődarab hevert. Az urak leültették K.-t a földre, a kőnek döntötték, és föltámasztották a fejét. Minden erőfeszítésük és K. minden előzékenysége ellenére: nagyon kényszeredett és hihetetlen volt a testtartása. Az egyik úr ezért megkérte a másikat: bízza rá egy időre K. lefektetését, de ettől sem javult a helyzet. Végül is olyan helyzetben hagyták K.-t, amely a már eddig elért helyzetek közül sem volt a legjobb. Ekkor az egyik úr kigombolta a kabátját, a mellényén feszülő öv tokjából hosszú, vékony, kétélű mészároskést húzott ki, magasra emelte, és megvizsgálta éleit a fényben. Újrakezdődtek az ellenszenves udvariaskodások, egyikük a másiknak nyújtotta K. fölött a kést, s az K. fölött újra visszanyújtotta. K. most pontosan tudta, hogy az ő kötelessége lenne megragadni és magába döfni a fölötte lebegő kést. De nem tette meg, hanem még szabadon hagyott nyakát forgatta, és körülnézett. Nem viselkedhetett tökéletesen, nem vállalhatta magára a hatóságok minden munkáját, ezért az utolsó hibájáért az felel, aki megtagadta tőle az ehhez szükséges erő maradékát. Tekintete a kőbányával határos ház legfölső emeletére tévedt. Ahogy a fény villan fel, úgy csapódott szét egy ablak szárnya, vézna, szikár férfi hajolt ki a párkányon, távol a magasban, s karját még messzebbre tárta. Ki volt az? Barát? Jólelkű ember? Valaki, akiben részvét élt? Valaki, aki segíteni akart? Egyetlen ember volt? Vagy mindenki? Volt még segítség? Volt még valami elfelejtett ellenérv? Nyilván volt. A logika ugyan rendíthetetlen, de nem tud ellenállni annak, aki élni akar. Hol a bíró, akit sohasem látott? Hol az a felső bíróság, ahová sohasem jutott el? K. fölemelte kezét, s széttárta minden ujját." Kafka, Franz: A per.

${ }^{4}$ BAHTYIN, M. M., A tér és az idő a regényben = B., M. M., A szó esztétikája, Bp., Gondolat, 1976, 257-258.
} 
tonális effektusok, az olfakció, a mechanikus érzékelés, a kinesztétikus érzékelés, az affektív érzékelés) szintjén konstituálódó térjelentéseket." (Faragó 2001: 42-43)

Nézetünk szerint Rilkével és Joyce-szal, Musillal és Kafkával jelölt irodalomtörténeti kiskorszak időszakában eltelő kőszegi három év élményanyagából táplálkozó regény, Ottlik Géza Iskola határonjának szövedéke hasonlóképpen épül fel amazokéhoz, s lehet akképpen a „posztmodernség” címszavával jelölt korszak meghatározó „prekorpusz”-a a magyar irodalomban. Vagy ha tetszik, másképpen szólva, a „megkésett magyar modernség" emblematikus darabja.

Gondolatkísérletünk lényege tehát az volna, hogy mindazok a problematikák, melyek tematikusan és poétikailag megjelennek eme irodalmi nagyrégióban, a (poszt)modernséget megelőlegezve, amannak jegyeit hordozzák magukban. Ilyen a szimmetrikus, egyenrangú szerkezetek megjelenése a szövegekben, ilyesmire utal a jelentések disszeminálódása, a tér- és idősíkok felbontása, a narrációs technikák (túl)bonyolítása, polifóniája, az elbeszéltség és megalkotottság tudatos érzékeltetése, továbbá és főképpen a nyelvproblematika és az emlékezetpoétika általánossá tematizálódása a szövegkorpuszokban.

Arra a kérdésre tehát, hogy hol kezdődött az (irodalompoétikai) posztmodernség Magyarországon, bízvást válaszolhatjuk, hogy a Nyugat-pannon régióban: megelőlegezve Berzsenyi Dániel időszemléletével, Ottlik Géza Iskola a határonjának nyelviségével, térés időszemléletével, narrációjával, kompozíciójával, mindezeket hipertextualitásával kiteljesítve, továbbá Weöres Sándor költői életművének tematikusan és érzelmileg ide kötődő részével, szerep- és világjátékaival gazdagítva - azaz mindhármójuk szószimfóniáival színesítve.

Merthogy műveik, amelyeket létrehoztak, a (poszt)modernség tapasztalatának nyelvi gesztusaival kiegészülve immár „nemcsak szól[nak] valamiről..., hanem inkább [maguk a] valami $[\mathrm{k}] . " 5$

\section{Irodalom}

Bahtyin, M. M. (1976): A tér és az idő a regényben. In: Uő: A szó esztétikája. Bp.: Gondolat Bányai Éva (2011): Leszúkített tér, regionalitás : Térképzetek, névtérképek, határidentitások: Kolozsvár: Kom-press

Faragó Kornélia (2001): A fikcionalitás tere. In: Uő: Térirányok, távolságok. Újvidék: Forum

Faragó Kornélia (2016): Idők, terek, intenzitások. Újvidék: Forum

Fried István (2002): A közép-európai szöveguniverzum. Bp.: Lucidus

Fried István (2010): Egy irodalmi régió ábrándja és kutatása. Bp.: Lucidus

Fried István (2010): Magyar irodalom(történet). Szeged: Tiszatáj-könyvek

Fried István (2014): Bolyongás a kelet-közép-európai irodalmi labirintusban : Egy soknyelvü, sokmüveltségü régió „természet”-rajza. Bp.: Lucidus

Fűzfa Balázs (2019): Gli inizi del postmoderno (?) : la prospettiva regionalista e la centralità di Trieste. Settentrione, vol. 31. 155-160.

Fűzfa Balázs (2006): „...sem azé, aki fut...” (Ottlik Géza Iskola a határon címü regénye a hagyomány, a prózapoétika, a hipertextualitás és a recepció tükrében). Bp.: ArgumentumMTA Irodalomtudományi Intézete (Irodalomtörténeti füzetek).

\footnotetext{
${ }^{5}$ Ottlik Géza levele Gara Lászlónak, közzéteszi Bende József (2002) Vigilia, 65(2), 119.
} 
Fűzfa Balázs (2010): Trieszt felé I-II. (Válogatott tanulmányok és egyéb írások [19862010]). Szombathely: Savaria University Press

Fűzfa Balázs (2017): A „Trieszti Öböl” mint szabadság-szimbólum. In: Uő.: Kifelé a ködből. Szombathely: Savaria University Press pp. 26-36.

Fưzfa Balázs (2013): A nyelvben megragadható világ kalandja : Tanulmányok a XIX-XX. századi magyar irodalomról. Szombathely: Savaria University Press

Fűzfa Balázs (2017): Kifelé a ködből : Irások Ottlik Géza műveiről. Szombathely: Savaria University Press

Györe Géza (2015): A horvát és a szerb irodalom magyar recepciója. Mutatványoldalak egy készülő bibliográfiából. Híd, 79(5), 27-51.

Hardi Tamás (2010): A Duna-térség megalkotása mint fejlesztési lehetőség Közép- és Délkelet-Európában. In: Losoncz Miklós - Szigeti Cecília (szerk.): Válság közben, fellendülés előtt. A Kautz Gyula Emlékkonferencia kötete, Győr: Széchenyi István Egyetem Kautz Gyula Gazdaságtudományi Kar, 17 p.

Jeney László (2013). A regionális szintek hierarchikus rendszere. [prezentáció] [online] cop. 2013 [2020. 11. 22.] <URL: https://slideplayer.hu/slide/2091239/

Kántor Lajos - Láng Gusztáv (1971): Romániai magyar irodalom 1945-1970. Bukarest: Kriterion

Kántor Lajos- Láng Gusztáv (2018): Száz év kaland : Erdély magyar irodalmáról. Csíkszereda: Bookart

Láng Gusztáv (1998): Kivándorló irodalom. Kolozsvár: KOM-PRESS Korunk Baráti Társaság

Musil, Robert (2013): A tulajdonságok nélküli ember. Bp.: Szépirodalmi (Tandori Dezső fordítása)

Németh Zoltán (2013): A szlovákiai magyar irodalom és a posztmodern fordulat. Esztergom és Vidéke, 1(1), 34-36.

Németh Zoltán (2014): Hálózatelmélet, kánon regionalitás. Tiszatáj, 68(5) 114-122.

Görömbei András szerk. (2000): Nemzetiségi irodalmak az ezredvégen. Debrecen: Kossuth Egyetemi Kiadó

Ottlik Géza (1975): Iskola a határon. Bp: Magvető

Papp Ágnes Klára (2011): Mágikus realista történelem. Korunk, 22(11), 3-7.

Pomogáts Béla (2005): Magyar régiók. Dunaszerdahely: Lilium Aurum

Pomogáts Béla (2009): Régió Európában: a Vajdaság. Zenta: Vajdasági Magyar Művelődési Intézet

Pomogáts Béla (2016): Magyar irodalom - határok nélkül. Pécs: Pro Pannónia Kiadói Alapítvány

Pomogáts Béla (2010): Regionális irodalom és nemzeti irodalom. Pannon Tükör, 15(3), $5-8$.

\section{SUMMARY}

„Did postmodern start here?"

Additional information about the evolution of literary consciousness in the bigger region of Trieste-Szombathely-Köszeg-Vienna-Prague during late modernism

Researchers have always been interested in the questions of literary regions, although with few exceptions - this point of view has never become a priority part of literature or the teaching of literature (it has been part of the latter one since 2005, the introduction of the two level matura exam).

The author builds his statement hypothetically on 20th century canonical works of art of world literature (Joyce, Musil, Rilke), or rather their poetic similarities, according to which 
one of the cradles of literary modernity could be the cultural channel of the Amber Road spanning over Europe, and Hungarian literature is its organic part as well - mainly by means of Géza Ottlik's novel entitled Iskola a határon. Ottlik's work of art processes the period (1923-1926), in which the characteristics of postmodern poetry appeared characteristically: coordination, parallel points of view, the break-up of timelines etc.

For example the „Bay of Trieste” (Joyce, Ottlik) becomes the cradle of modernity in a way that the road spans from Duino (Rilke) over Trieste and Szombathely (Joyce), furthermore Köszeg (Ottlik) to Vienna (Musil) and Prague (Kafka). A series of thematic problems can be highlighted (among other things), like for example the possible point of view of „military school author"-s; which is essentially the determinant point of view of a literary scholar creating in the same period together with them, that is the military school-texts determined by their "chronotopos" feature (Bahtyin).

The main hypothesis indicated in the title („Did postmodern start...”) may as well be said to be exaggerated or playful, but the author hopes that his point of view can contribute to the interpretation of the poetic world of the small period concerned with some additional information.

Keywords: postmodern, grand region, Joyce, Kafka, Musil, Ottlik, Rilke 